Mirjam Lepikult

\title{
MICHEL FOUCAULT’ FILOSOOFILINE NÄGEMINE KUJUTAVA KUNSTI NÄITE PÕHJAL
}

Michel Foucault'le iseloomuliku nägemisviisi teema sai siinkirjutaja jaoks alguse filosoofi esimest suurteost („Hullust ja arutust“) tõlkides. Tõlkija suhe tekstiga erineb mõnevõrra lugeja suhtest. Kui viimane loeb teksti teadmiste hankimise, isikliku huvi või naudingu pärast, siis tõlkijana tuleb maksimaalse tähelepanuga süüvida, võiks isegi öelda, siseneda autori mõttemaailma, et sinna sisse elanuna püüda üles ehitada samasugust mõttemaailma juba oma emakeeles. Foucault' looming pakkus ainulaadse tõlkimiskogemuse, osutudes selgelt nähtavaks. Tekst pani kujutlusvõime erksalt tööle, tekitades „elavaid pilte“ - enne veel, kui sõnastus järele jõudis, hakkas autori kirjeldatav olukord või "pilt“ kujutlusvõimes oma elu elama ning visuaalsed elemendid nihkusid otsekui ise oma kohale, aidates nõnda täpsema sõnastuseni jõuda.

Niisiis piirdus esialgu kõik tõlkija "toorevõitu“ ettekujutusega Foucault' mõttemaailma omapärast - filosoofilise teksti puhul erandlikult silmatorkavast visuaalsusest. Ajapikku selgus siiski, et foucault'liku nägemise teema on köitnud nii mõnegi filosoofi (näiteks Gilles Deleuze'i ja Michel de Certeau) tähelepanu. Deleuze oli veendunud, et visuaalse aspekti eiramine või vääritimõistmine moonutaks Foucault' kontseptsiooni ajaloost, aga ka kogu tema mõtteviisi sedavõrd, et sellest saaks „tänapäevase analüütilise filosoofia üks variant, millega sel pole tegelikult kuigi palju ühist". ${ }^{1}$ Deleuze'ile kuulub ka kogu probleemi kõige kokkuvõtlikum määratlus: filosoofiline nägija on tema sõnul see, kes

DOI: http://dx.doi.org/10.12697/BJAH.2016.11.05

1 Gilles Deleuze, Foucault (Paris: Minuit, 1986), 57. 
näeb midagi, mida veel pole nähtud. ${ }^{2}$ Näiteks nägi Foucault avalike ruumide korralduses seda, mida samal ajal keegi teine ei näinud, aga mida pärast Foucault' analüüsidega tutvumist on juba raske mitte märgata. Filosoofiline nägemine on Deleuze'i sõnul (nii Foucault'l kui ka paljudel teistel filosoofidel) olemuslikult seotud „evidentsi katkestamisega“, see tähendab, silmanähtavuse, ilmselguse, enesestmõistetavuse lõhkumisega ning kujutab endast sellisena mõtlemise kriitilist avamist. Ka M. de Certeau on juhtinud tähelepanu Foucault’ loomingu „kummalisele, aga siiski kõikeläbivale aspektile: selle visuaalsele karakterile. ${ }^{\text {“3 }} \mathrm{Ta}$ leidis Foucault” „pilte“ analüüsides, et just need (nii jutustatud kui ka kujutavad pildid) panevadki diskursusele aluse. Foucault tunneb piltides ära "erinevuse stseeni“, „teisesuse sädeme“, mis pole mitte mingit liiki tõestus, vaid hoopis üllatus. „Kogu diskursus kulgeb niiviisi ühelt visioonilt teisele. Just visuaalne moment on see samm, mis tähistab diskursuse käigu rütmi; visuaalne moment toetab diskursuse käiku ja annab talle impulsi. ${ }^{\text {"4 }}$ Certeau sõnul leidub Foucault' loomingus igal sammul üllatusepuhanguid (mis sarnanevad palavikuhoogudega), äkilisi vaimustusehooge, peaaegu ekstaatilisi „üllatuse“ või „imestuse“ vorme, mis on ajendanud mõtlejaid filosoofilisele tööle Aristotelesest Wittgensteinini. „Miski, mis ületab mõeldava ja avab „teistmoodi mõtlemise“ võimaluse, murrab diskursusse sisse koomiliste, ebakongruentsete või paradoksaalsete praotuste kaudu. “5 Ja filosoof, keda valdab naer, asjade eneste iroonia, mis on samaväärne valgustusega, ei ole nende etableerunud mõistusesüsteemide rajatud diskursusevõrgustikku läbivate ja ületavate sähvatuste autor, vaid tunnistaja. ${ }^{6}$

Üllatus, imestus, vaimustus, lummus, naer... Need tavapäraselt pigem kunstiga seotud märksõnad meenutavad, et filosoofia territoorium asubki vaimses kultuuris teaduse ja kunsti vahel ning et Michel Foucault liikus oma mõtterännakutes selle territooriumi ühest servast teise kergemini kui nii mõnigi teine professionaalne filosoof. Siit tulenebki esimene põhjus keskenduda käesolevas artiklis, mis vaatleb Michel Foucault' eriomast nägemisviisi, eelkõige kujutava kunsti temaatikale. Teine põhjus

2 Jan Rajchman, „Foucault's Art of Seeing“, October, 44 (1988), 16. (Viide intervjuule Gilles Deleuze’iga ajakirjas History of Present, spring/1986.)

Dichel Foucault", Michel de Certeau, Heterologies: Discourses (1986), 196.

De Certeau, „The Laugh of Michel Foucault", 196.

(16) seisneb selles, et just kujutav kunst paigutab filosoofi kõige otsesemalt vaataja rolli. Rohkem on küll uuritud foucault‘likku järelevalvetemaatikat, kuid valvav pilk ei ole sugugi sama, mis filosoofi „lugev“ pilk. Pealegi suhtus Foucault ise kõikehõlmavasse järelevalvesse varjamatu skepsisega. Seevastu kujutav kunst annab hea võimaluse tuua esile tema enda „nägemiskirge“ (nagu ütles G. Deleuze”).

\section{VERTIKAALNE KUNSTINÄGEMINE}

Piltide, nende lummuse ja peateema kohaselt muidugi ka hulluse suhte kohta leidub Foucault" „Hulluses ja arutuses” (1961) palju eredaid näiteid. Võiks isegi öelda, et pildid „,vohavad“ selles teoses, mille autor näib olevat kirja pannud ühe hingetõmbega, vaevumata vältima kordusi ja hoidmata tekstiruumi kokku nendesamade värvikate näidete arvelt. Siinkohal peame mõistagi piirduma väheste näidetega, tõstes omalt poolt kursiiviga esile vertikaalsusele viitavat sõnakasutust.

„Omal ajal pakkus kimäär näitliku õppetunni sellest, kuidas himura inimese hing on langenud looma vangistusse. /---/ Nüüd aga, 15. sajandil, saab kimäärist, sellest inimliku hulluse kujutisest üks loendamatute Kiusatuste lemmikfiguure. Eraku rahu ei ründa mitte need asjad, mille järele käib inimlik himu, vaid nõdrameelsed, saladusse mähkunud vormid, mis on üles kerkinud unenäost ning võbelevad nüüd vaikides ja põgenemisaltilt maailma pealispinnal.“8

Edasi küsib Foucault: „Milline siis on see lummav vägi, mis ennast tol ajajärgul hulluse piltides ilmutab? ${ }^{\prime \prime 9}$ (Jätkem meelde sõnapaar „lummav vägi“, sest hiljem, kui Foucault loobub heideggerlikust olemismõistest ja see asendub võimumõistega, võim aga omakorda tähendab ,jõudude vahekorda", näeme, et just selles jõus või väes seisneb üks tema varajast ja hilist loomeperioodi seesmiselt ühendav telg.) „Kohal on ainult jõud - kõikidest jõududest kõige seesmisem ja samas ka kõige metsikumalt vaba jõud, toosama, mis kisub kehasid tükkideks „,Suures unes“, toosama mis rebib end ahelaist lahti ja kaeverdab silmi "Märatsevas hulluses“. /---/ Ei ole enam silmi ega suid, on ainult pilgud, mis tulevad eikuskilt

\footnotetext{
Deleuze, Foucault, 58

Michel Foucault, Hullus ja arutus. Hullumeelsuse ajalugu klassikalisel ajastul, tlk Mirjam Lepikult Tartu: Ilmamaa, 2003), 36-37.

9 Ibidem.
} 
ja sihivad eimiskit (nagu „Nõiasabatis“), või siis karjed, mis kostuvad mustadest aukudest (nagu „Püha Isidoruse palverännakus“). ${ }^{\prime 10}$

Üks neist „lummavatest vägedest“ on inimese loomalikkus: „Kui patune inimene viimselpäeval kogu oma tülgastavas alastuses välja ilmub, siis selgub, et ta näeb välja nagu koletu, jampslik loom. Need on kärnkonna keredega hüaankassid, keda võib leida Thierry Bouts'i Põrgus hukkamõistetute alasti kehade massis; need on Stephan Lochneri laadis tiivulised putukad, kassi peaga liblikad, maipõrnika tiibadega sfinksid ning linnud, kelle tiivad on erutavad ja ahned nagu käed; see on suur, pahklike sõrmedega röövloom, kes esineb Grünewaldi Kiusatusel.."11

„Kummalise paradoksina olid ka kõige iseäralikumad deliiriumi sünnitised juba eelnevalt nagu mingi saladusena või kättesaamatu tõena maa rüpes varju. “12

„Ühel pool seisavad Bosch, Brueghel, Thierry Bouts ja Dürer, ning seal valitseb täielik piltide vaikus. Hullus päästab oma väed valla puhtvisuaalses ruumis. Fantasmides ja ähvardustes, unenägude puhastes näivustes ja maailma salajases saatuses - seal säilitab hulluse ilmutus esialgse jõu. Esiteks ilmutab ta, et unenäoline on reaalne, et illusiooni õhuke pealispind avaneb vaid vastupandamatu sügaviku kohal ning et pildi hetkeline sähvatus ei päästa maailma nende ängistavate figuuride küüsist, mis igavesti olelevad tema öödes. Ja vastupidises, kuid niisama haigettegevas ilmutuses kuulutab ta, et kunagi laguneb ja sulab kogu maailma reaalsus fantastilises Pildis - sel olemise ja olematuse vahelisel hetkel, mis on puhta hävitamise deliirium; maailma ei ole enam, kuid ka öö ja vaikus ei ole teda veel täiesti endasse neelanud. Maailm väreleb viimses puhangus, viimses kaoses, millele kohe järgneb lõpetatuse monotoonne kord. Just selles ainsa hetkega hävivas pildis läheb kaotsi maailma tõde. Kogu see nähtavuse ja saladuse, otsese pildi ja varulhoitud mõistatuse kangas rullub XV sajandi maalikunstis lahti maailma traagilise hullusena." ${ }^{13}$

Nagu eeltoodud tsitaatides mitmel pool märgata võib, kõneles Foucault kunstiteostega seotud kujundlikus keeles sellest, et hullus koos oma piltidega oleks justkui varjul maailma öödes, unenägude sügavuses või otseselt maa enda põues. Maalikunstnikke (Boschi, Brueghelit, Dürerit) iseloomustades kasutas ta väljendit terriblement terrestres ${ }^{14}$ - seega siis

\footnotetext{
10 Foucault, Hullus ja arutus, 793.

11 Ibidem, 38.

12 Ibidem, 40

14 Ibidem, 46.
}

"hirmuäratavalt maised“ ja sõnamänguna veidi ka „maisemast maisemad“ vaatlejad, kes olid "ka ise haaratud hullusest, mida nad nägid kõikjal enda ümber maast välja vohavat. ${ }^{\prime \prime 5}$ Ja sealtsamast maapõuest, kust hullus välja „vohab“, kasvavad välja ka hullust väljendavad pildid: „Boschil ja Brueghelil sündisid need vormid maailmast endast: kasvasid läbi kummalise poeesia pragude välja kividest ja taimedest, kerkisid esile loomalikkuse sügavikust.." ${ }^{\prime 16}$

Sellise visiooni taustalt kumab läbi Martin Heideggeri mõju Foucault ${ }^{\prime}$ õpiaastatele, mille kohta ta ise ütles, et ,,kogu minu filosoofiline kujunemistee on olnud mõjutatud Heideggeri lugemisest", ning et Heidegger on teda alati lummanud, aga ta ei suutnud Heideggeri mõista teisiti kui Nietzsche kaudu ja koos Nietzschega, mitte vastupidi. ${ }^{17}$ Milles siis võiks näha Heideggeri mõju Foucault‘ kunstinägemisele „Hulluses ja arutuses"?

Kõigepealt võiks Foucault' jutt maas peituvast, maast välja kasvavast hullusest ja piltidest paista üsna suvalise kujundina, kui mitte pidada silmas Heideggeri teost „Kunstiteose algupära“, kus ta ütleb: „Millesse teos tagasi seadub ning millel ta selles tagasiseadumises esile tulla laseb, seda nimetasime maaks. Maa on esiletulevalt varjav. Maa on see eimillekski sunnitud vaevatu-väsimatu. Maale ja maasse põhjab ajalooline inimene oma asumise maailmas. Üht maailma üles seades seab teos esile maa. Esileseadmine on siin mõteldav sõna ranges mõttes. Teos nihutab maa enda ühe maailma avatu'sse ning hoiab teda selles. Teos laseb maal olla maa. ${ }^{\prime 18}$ Ja veel tuleb siinkohal rõhutada Heideggeri kunstikäsitluse üht kandvat joont - tõdemust, et ",teoses on /---/ teoksil tõe loodumine“". ${ }^{19}$

Sellise kunstinägemise valguses on paremini mõistetav ka viis, kuidas Foucault püstitab hulluse, piltide ja sõnade suhte probleemi: „Pigem tuli seal ilmsiks too loomingu jaoks keskne ebakindlus, milles teos üldse ilmale tuleb; see tähistas momenti, mil lõpeb teose sündimine ja ta saab tõeliseks, olemasolevaks. /---/ Kas teose tõde peab olema (isegi juba enne sündi) seatud kõrgemale inimese enda armetust tõest, või tuleb see avastada kaugel tagapool tema enda algust - olemises, mida ta eeldab? "20

Niisiis, asi on loomingu jaoks keskses ebakindluses, mille kohta Foucault ütleb, et selleta ei saagi looming ilmneda, olemasolevaks

15 Foucault, Hullus ja arutus, 46

16 Ibidem, 792.

17 Vt Deleuze, Foucault, 120-121.

18 Martin Heidegger, Kunstiteose algupära, tlk Ülo Matjus (Tartu: Ilmamaa, 2002), 44.

19 Heidegger, Kunstiteose algupära, $32-33$.

20 Foucault, Hullus ja arutus, 799-800. 
saada. Looming tähendab ju olemasoleva piiride rikkumist, millegi uue sündi. Ebakindluseta poleks see riskantne uudsus ja vabadus võimalik. Hulluseski peitub ebakindlus, ettearvamatus, ja võiks ehk oletada, et just sel põhjusel kuulub Foucault' sümpaatia "Hulluses ja arutuses“ pigem "hulludele“, inimestele, kelles saab ilmsiks too ebakindlus, riskantne vabadus. Sama põhjusega - hädavajaliku ebakindlusega - võiks vast seletada ka Foucault' kirglikku huvi piltide vastu, millel ta end nii meelsasti lummata laskis (nagu loodetavasti paistab välja eeltoodud üsna pikkadest tsitaatidest). Pigem just keel, terminoloogia, diskursus - kõik öeldav, sõnaline - oli vaadeldaval ajajärgul see, mis püüdis hullust sisse mähkida, kustutada (kaasa arvatud ühiskonna silme alt) ning vaikima sundida. Seetõttu jäidki kunstiteosed hulluse kui „traagilise kosmilise kogemuse“ peamiseks pelgupaigaks ning Foucault vastandas "kosmilise nägemuse figuure" ja "moraalseid mõttekäike" , "traagilist elementi“ ja "kriitilist elementi“, väites, et „veatu sirgjoon, mis juhib ratsionaalset mõtlemist hulluse analüüsimisele vaimuhaigusena, tuleb vertikaalses mõõtmes ümber mõtestada. Siis selgub, et ratsionaalsus varjab kõikide oma järjestikuste vormide all üha täielikumal ja samas ka üha riskantsemal viisil traagilist hullusekogemust, mida ta pole siiski suutnud jäägitult olematuks muuta. Kui surve jõudis viimase piirini, pidi paratamatult toimuma plahvatus, ja selle tunnistajaks me pärast Nietzschet olemegi.“21

"Hulluses ja arutuses" kirjeldab Foucault" pilte nii sugestiivselt, et õigupoolest „maalib“ need sõnadega uuesti lugeja kujutlusilmas. Teda kui filosoofi ei häiri üldse, et pildid teda mõneks ajaks - sõnade leidmiseni - vaikima sunnivad. Selles vaikuses peitub vabadus. Veel pole teada, milliste sõnadega saab kirja pandud "filosoofiline pilt“. Teksti lugedes annab lugeja end autori meelevalda - tema mõttelõng järgib etteantud joont, ning sellest eraldumiseks tuleb lugemine katkestada. See muidugi ei tähenda, et lugeja enda kujutlusvõimele ja mõtlemisele seejuures üldse vabadust ei jääks - inimene pole ometi koopiamasin! -, aga siiski on lugemisvaikus nägemisvaikusest mõnevõrra erinev.

Selle põhjust pole raske mõista, kui pidada silmas, et väed või jõud lähtuvad siin veel maailmast või täpsemalt öeldes olemisest. Kui vaadata kunstiteost tõe loodumisena, siis pole midagi imelikku selles, et vaataja vaevub olema retseptiivne või aupaklik. Siia söandame lisada ühe pigem kujundliku kui range märkuse Foucault' vertikaalse näge-

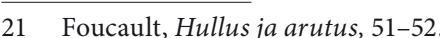

mise kohta (nii nagu see avaldus „Hulluses ja arutuses“): veel vaatab ta piltidele „alt üles“, imetluse, üllatuse, lummuse ja aukartusega, sest teoses on ju tõde teoksil. Kui aga tõde hakkab sündima tõerežiimi kaudu, mitte maailmast endast, siis asetab Foucault ennast diskursiivse praktika poolele ja vaatab piltidele kui nähtavustele (mittediskursiivsusele) juba „ülalt alla”.

\section{HORISONTAALNE KUNSTINÄGEMINE}

1969. aastal ilmunud „Teadmiste arheoloogia“ lehekülgedelt on kunsti jälgi mõnes mõttes lihtsam leida kui „Hullusest ja arutusest“. Viimases leidub neid nii palju ja piltide kirjeldused on nii sugestiivsed, et raske on tulla nähtava lummusest tagasi öeldavasse. Seevastu oma „,arheoloogilise" loomeperioodi tippteoses puudutas Foucault kunsti põgusalt ainult mõnes üksikus kohas ja päris otseselt ainult ühes. Seal visandatud võimalik arheoloogiline kunstikäsitus kõlab järgmiselt: „Arheoloogilisel analüüsil oleks aga teistsugune eesmärk: ta uuriks, kas ruum, distants, sügavus, värv, valgus, proportsioonid, volüümid, kontuurid olid tol ajajärgul nimetatud, lausutud, kontseptualiseeritud diskursiivses praktikas ja kas teadmine, millele see diskursiivne praktika aset annab, sisaldub teooriates või spekulatsioonides, õpetamisvormides ja retseptides, aga ka meetodites, tehnikates ja peaaegu et kunstniku enese žestis. Tegu poleks näitamisega, et maalikunst on teatav tähistamise või „ütlemise“ viis, mille eripära on see, et ta saab läbi sõnadeta. Näidata tuleks seda, et vähemalt ühes oma dimensioonis on ta diskursiivne praktika, mis kehastub tehnikates ja tulemustes. Niimoodi kirjeldatuna ei oleks maalikunst puhas visioon, mis kirjutatakse ümber ruumi materiaalsusesse ta pole ka mitte paljas žest, mille vaikivad ja igavesti tühjad tähendused tuleks vabastada igasugustest hilisematest tõlgendustest. Teda läbib tervenisti - sõltumatult teaduslikest teadmistest [connaissance] ja filosoofilistest teemadest - ühe teadmise [savoir] positiivsus. ${ }^{\text {“22 }}$

Oma nn arheoloogilisel loomeperioodil loobus Foucault Edmund Husserli fenomenoloogia universaalsest moodustavast subjektist, Heideggeri olemise valendikust ja Maurice Merleau-Ponty toorest kogemusest, üldse aprioorsetest tingimustest, ning asendas need ajalooliste tingimustega. Deleuze rõhutas just seda perioodi, selgitades, et siin

22 Michel Foucault, Teadmiste arheoloogia, tlk Kaia Sisask (Tartu: Tartu Ülikooli Kirjastus, 2005) $168-169$ 
annab Foucault diskursiivsusele mittediskursiivsuse ees ilmse eesõiguse, kuid samas ei väida ka kunagi, et mittediskursiivust justkui olemas ei oleks või et seda „vaja“ poleks. Öeldav ja nähtav on Foucault'l alati kaks heterogeenset vormi, need on loomult erinevad, kuid eeldavad teineteist vastastikku, ,embavad ja ajavad teineteist taga“, nagu ütleb Deleuze. ${ }^{23}$ Ka oma eelmainitud kunstiarheoloogia visandis jätab Foucault võimaluse avatuks, öeldes, et kunst on diskursiivne praktika „vähemalt ühes oma dimensioonis“. See ju viitab võimalusele, et kunstil on dimensioone rohkem. Mida ta silmas peab? Praegu aga vaatame Foucault' kunstinägemist sealt, kus see lähtub - diskursuse väljalt. Iseloomustamaks seda positsiooni, püüame taas jälgida suunda, mille Foucault' pilk siin võtab. Kas vertikaalsuund on säilinud või avaldub see varasemaga võrreldes kuidagi teisiti? Kõigepealt otsime „Teadmiste arheoloogiast" vertikaalsusele viitavat sõnakasutust ja tõstame need kohad omalt poolt kaldkirjas esile.

„Niimoodi kirjeldatud strateegiate juured ei peitu valiku tummas diskursuse-eelses sügavikus, mis on ühtaegu diskursust ettevalmistav ja fundamentaalne. ${ }^{\text {“24 }}$ "Niimoodi kirjeldatud mõistete-eelsus ei visanda mitte horisonti, mis ajaloo sügavusest esile kerkiks ja püsiks, vaid annab oma kõige "pinnalisemal" (diskursuse) tasandil - hoopis rea reegleid, mida seal tegelikult on rakendatud. ${ }^{\prime 25}$

„Sellises analüüsis, mille ma olen ette võtnud, puuduvad sõnad sama otsustavalt nagu asjad; enam ei kirjeldata sõnavara ega pöörduta kogemuse elava täiuse poole. Me ei tule tagasi diskursuse-eelse seisundi juurde, kus pole veel midagi öeldud ja kus asjad alles vaevu tärkavad hallis valguses; me ei lähe teispoole diskursust, et leida üles vormid, mille ta on loonud ja selja taha jätnud - me jääme, me püüame jääda diskursuse enda tasandile. /---/ ... tahaksin näidata, et ",diskursused“, nii nagu neid võib kuulda või lugeda, ei ole, vastupidiselt ootustele, asjade ja sõnade lihtne lõikepunkt: asjade ähmane lõim ja sõnade ilmne, nähtav ja värviline ahel; ma tahaksin näidata, et diskursus pole õhuke kontakti- või vastuolupind reaalsuse ja keele vahel või leksika ja kogemuse keerukus; ma tahaksin näidata konkreetsete näidete varal, et analüüsides diskursusi endid, võib näha lõtvumas sõnade ja asjade pealtnäha nii tugevat embust ja tekkimas diskursiivsele praktikale omast reeglite kooslust. ${ }^{\text {}} 26$

23 Deleuze, Foucault, 74

24 Michel Foucault, Teadmiste arheoloogia, 65

25 Ibidem, 60.
Siin räägib Foucault sügavikust - diskursuse-eelsusest -, kuid alati negatiivses võtmes, deklareerides, et ta enam sinna ei lähe. Arheoloogiline analüüs peaks tema järgi toimuma diskursuse tasandil, mis on „kõige pinnalisem“. Nagu öeldud, ei eita Foucault mittediskursiivse, diskursuse-eelse "kihi“ olemasolu, kuid ta valik langeb siin "pinnalise“ nägemise kasuks. Võttes arvesse just seda „,kõige pinnalisemat“ tasandit, jõuame järeldusele, et filosoofi pilk liigub nüüd mööda seda pinda, seega horisontaalselt.

Olgu mainitud, et säärasest horisontaalsest (pinnalisest) kunstinägemisest leidub teisigi näiteid, tegelikult vertikaalsed ongi vähemuses. Ühe markantsema näite horisontaalsest kunstinägemisest pakub George Dickie oma institutsionaalse kunstiteooriaga, mille ta avaldas trükis 1974. aastal (niisiis „,ajaloolise koe sees“ mitte kaugel Foucault’ kunstinägemise horisontaliseerumisest), pakkudes välja järgmise definitsiooni: „Kunstiteos, liigitavas tähenduses, on (1) artefakt, (2) see, mille reale tahkudele on keegi isik või isikud, kes tegutsevad teatud sotsiaalse institutsiooni (kunstimaailma) nimel, andnud hindamise kandidaadi (candidate for appreciation) staatuse. ${ }^{\prime 27}$ Selline institutsionaalsuse mõiste kutsus esile palju kriitikat, mispeale Dickie pidi täpsustama, et ta ei pea silmas mingit „,klikki“, vaid teatud informaalse kultuuri praktikat, tausta, mis teeb kunsti loomise võimalikuks. 1984. aastaks muutis ta oma käsitust selle võrra, et institutsiooni ei moodustagi isikud, vaid kunst kui sotsiaalne praktika koosneb mitmesugustest konventsioonidest ja reeglitest, mis määratlevad eelkõige kunstniku ja publiku rolli. Püüdes nüüd Dickie teooriat visualiseerida, näeme, et sellel puudub vertikaalmõõde. Kunst toimub tervenisti teatud praktika raames tegutsevate ja kõnelevate isikute vahel. Kõik piirdub staatuse andmise, pildi esitamise ja hinnangu vastusaamisega.

Taas vaatenurka vahetades küsime edasi: kas niisugune nägemine, mis vaatleb kunsti diskursiivse praktikana, diskursuse „kõige pinnalisemal“ tasandil, nagu Foucault ütles, on visualiseerides tõepoolest täiesti kahemõõtmeline? Näiteks „Teadmiste arheoloogia“ peatükis „Objektide moodustamine" hullumeelsuse kui objekti moodustumist käsitledes leidis Foucault, et kõigepealt tuleks „kaardistada nende (diskursuseobjektide) esmased ilmumispinnad: näidata, kus need individuaalsed erinevused /---/ võivad esile kerkida, et neid seejärel saaks nimetada ja

27 Margit Sutrop, „Mis on kunst? Institutsionaalse esteetika kimbatus“, Akadeemia, 8 (1998), $1657-1658$. 
analüüsida.“28 19. sajandil hakkasid Foucault' sõnul toimima hullumeelsuse uued ilmumispinnad, millest esimesena ta nimetab „kunsti tolle isikliku normatiivsusega“, edasi seksuaalsust ja karistussüsteemi. Kuigi kunsti nimetatakse siin otsesõnu (ilmumis)pinnaks, kõneleb Focault ikkag erinevuste esilekerkimisest. Viimane pole mõistagi kuigivõrd range termin, aga võimalik, et selline sõnavalik tuleneb Foucault' enda nägemisest, mille järgi mittediskursiivsus asetseb diskursiivsuse all. Seepärast näib, et nüüd vaatab ta piltidele pigem „ülalt alla“, mitte „alt üles“ nagu „Hulluses ja arutuses“. Ja mis suunas õigupoolest toimub kunstiloome juhul, kui seda nähakse „visiooni ümberkirjutamisena ruumi materiaalsusesse“?

\section{SFÄÄRILINE KUNSTINÄGEMINE}

Kunstinägemise viis, mida siin nimetame „sfääriliseks“, sai Michel Foucault' loomingus valdavaks 1970. aastatel, mil tema huvi keskmesse tõusis võimutemaatika. Ta on ise „Hullusele ja arutusele“ tagasi vaadates kriitiliselt öelnud: „Arvan küll, et ma tollal oletasin mingisuguse elava, sõnaohtra ja rahutu hullumeelsuse olemasolu, mida siis võimu mehaanika ja psühhiaatria on tulnud ära keelama ning vaikima sundima. ${ }^{\text {“29 }}$ Hiljem, olles loobunud nii ontoloogiast kui ka fenomenoloogiast, samuti "toorest" kogemusest, püüdis ta selgitada, kuidas „objektid“ moodustuvad vahetult ajaloolise koe sees, ilma mingi moodustava subjektita. Seega pole ka kunstis enam esmatähtis kunstnik ise, see „moodustav subjekt”, ja mõneti paradoksaalsel kombel isegi mitte teos, vaid seda ümbritsev "kude" - kõikvõimalikud sotsiaalsed ja ajaloolised võrgustikud, funktsioonid, reeglid, sealhulgas diskursus, ohjeldamatult vohav tekstitihnik. Kogu ühiskondlikku kehandit läbiv võimu "produktiivne võrgustik“ ei ole aga lame, pinnaline, vaid omal moel ruumiline. Foucault' võimumaailm paistab siiski teatud mõttes sarnane Heideggeri olemise maailmaga - sarnasus seisneb mõlema ruumilisuses. Ainult et Foucault ${ }^{\prime}$ võimumaailmas toimivad üksnes reaalsed asised jõud, mitte niivõrd olemise sügavad vood või „,universumi tumedad kiired“, nagu on öeldud Heideggeri ontoloogia kohta. Seepärast, kui siinkirjutaja püüab võimumaailma visualiseerida, paistab see pigem suletuna, sfäärilisena, mitte avatuna nagu olemine oma isepuhkemises.

28 Foucault, Teadmiste arheoloogia, 41-42.

Tichel Foucault Tõde ja võim", Teadmine, võim, subjekt. Valik räägitust ja kirjutatust (Tallinn Varrak, 2011), 241.
Mis saab siis säärases võimuvõrgustikus kunstist? Üks Foucault' võimudefinitsioonidest (või pigem iseloomustustest) kõlab järgmiselt: iga vorm on jõusuhete kompositsioon; kui jõud on antud, küsitakse endalt esiteks, milliste väljaspoolsete jõududega need suhestuvad, ja siis, milline vorm neist sünnib. ${ }^{30}$ Oleks ehk huvitav analüüsida selle määratluse alusel üht juhtumit, millest on kirjutanud Peeter Mudist oma raamatus „Ratsukäik“: „Kui võtta põllukivi, siis alguses käsi ei tõuse teda muutma või talle uut nägu andma, see oleks nagu käe tõstmine elava asja vastu. Enne ma ei saanud aru, miks neil kividel niisugune külgetõmme on. Alles tüki aja pärast taipad, et see tuleneb meie ajaloost. Kui mõelda, siis kõik need kivikalmed on ju põllukividest tehtud. Kivi on üks põhiline asi eestlase jaoks - see on püüd jäävuse ja muutumatuse poole. Üks esimesi kiviportreid, mis ma tegin: ma sõitsin jalgrattaga ja järsku mulle tundus, et miski pole päris korras. Keerasin tagasi, läksin tüki maad põllu peale, ja seal ta oli. Ja tõesti - niisugune kivi, mida ma hiljemgi ei ole kusagilt mujalt saanud. See oli mingi põhjafraktsioon, viimane jääk või niisugune sade... „Patsi“ on selle kuju nimi praegu. ${ }^{\text {“31 }}$

Kas võiksime siit leida jälgi nii Foucault' varajase perioodi kui hilisema perioodi vaadetest? Kas see maa pinnale kerkinud „põhjafraktsioon, jääk või sade“" või ka kivide ja kunstniku vastastikune tõmme võiks kõlada kokku Foucault' varajase, Heideggeri mitte-esteetilisest kunstikäsitusest mõjutatud vaateviisiga? Ja mis puutub võimufilosoofiale vastavasse jõusuhete kompositsiooni, siis näeksime huvitavat „pilti“ juba üksnes antud juhtumist erinevaid jõudusid „välja noppides“: elava asja jõud, mis hoiab skulptorit kätt kivile külge panemast; kivide mõistatuslik külgetõmbejõud; muinasusundi jõud; kalmete ja surma jõud; jäävuse ja muutumatuse püüu jõud; jalgratta ja sõidu jõud; kivi kui põhjafraktsiooni jõud; maapõuejõud, mis kive põllupinnale kergitavad; kivi raiumiseks vajalik jõud, skulptuur „Patsi“ jõud jne; viimaks veel see tundmatu jõud, mis sundis jalgratturi tagasi keerama ja tüki maad põllu peale minema, „sest miski polnud päris korras“. Kui visualiseerida kõike seda liikuva pildina - kas näeme siis toimuvat vertikaalse, horisontaalse või sfäärilisena? Ja kui võtta vaevaks vaadata järgemööda kõiki kolme moodi, mis siis muutub pildil ja meie järeldustes?

30 Deleuze, Foucault, 131

31 Peeter Mudist, Ratsukäik (Tallinn: Hilana, 2002), 290 


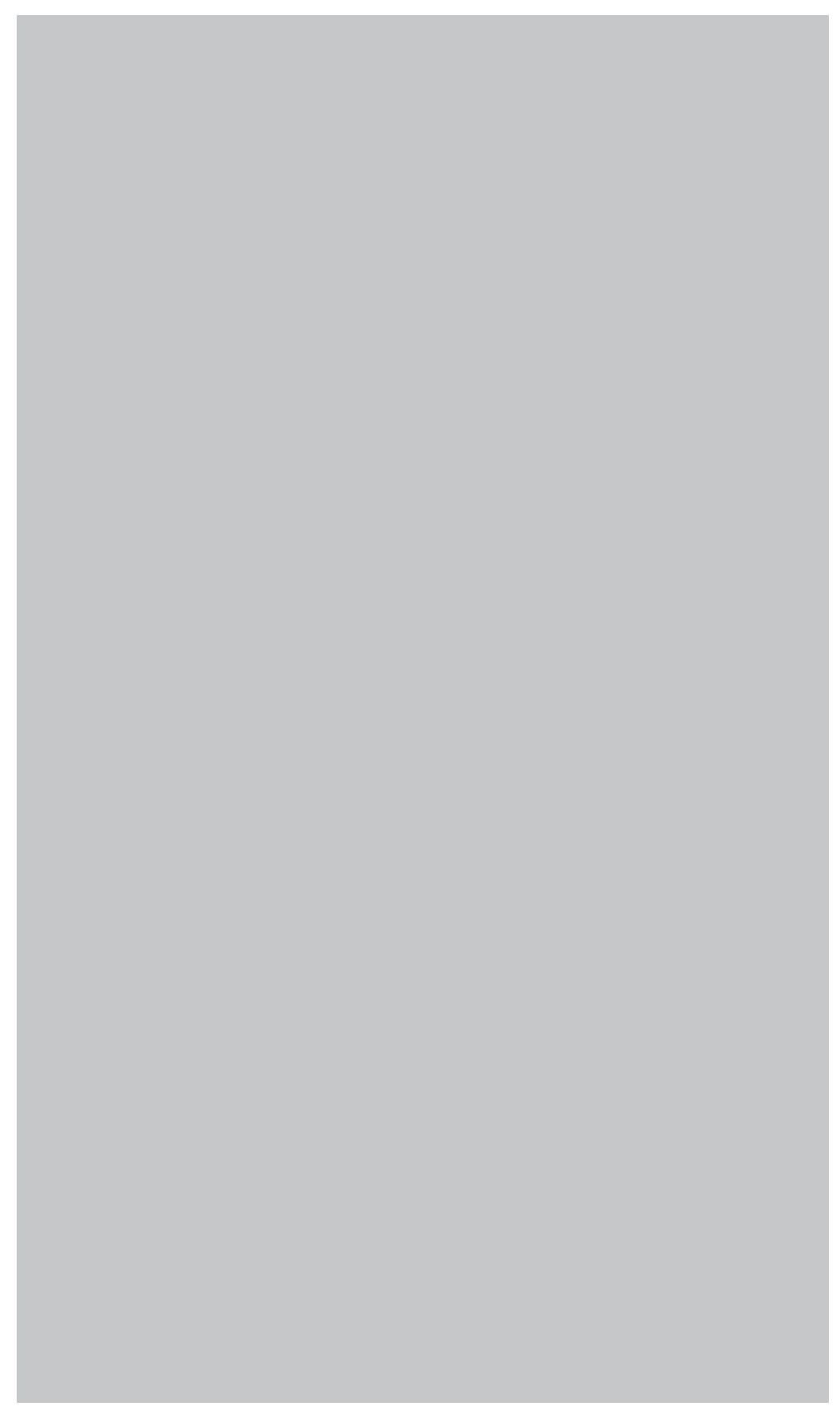


Foucault' juurde naastes nentigem, et teatud mõttes liikus ta oma "Seksuaalsuse ajaloos" võimupõhise kunstifilosoofia poole, ainult et - talle nii omase ettearvamatusega - seal pole kõne all mitte niivõrd traditsiooniline kujutav kunst, vaid „eksistentsiesteetika“. Teos ei olegi enam ilmumispind, vaid inimesest endast hakkab kujunema teos - nii „heas“ kui ka „halvas“ mõttes. Foucault kuulutas, et „kõik on ohtlik“ mitte, et miski on halb ja miski on hea.

Lõpuks võiksimegi vaadelda Foucault' sfäärilist kunstinägemist sellesama tõdemuse - „Kõik on ohtlik!“ - valguses.

1973. aastal ilmunud raamatus „See ei ole piip“ (mis sai alguse René Magritte'iga peetud kirjavahetusest) kirjeldas Foucault sõna ja kujutise suhet järgmisel dünaamilisel ja ruumilisel moel: „Niisiis tuleb tunnistada, et kujundi ja teksti vahel esineb terve rida läbipõimumisi või pigem ühelt teisele suunatud rünnakuid, vastasmärklaua pihta heidetud nooli, õonestus- ja hävitustegevusi, piitsahoope ja haavu; lahinguid." ${ }^{\prime 32}$ "Ja siis tekivad selles lõhestatud ja triivivas ruumis kummalised seosed, toimuvad sissetungid, äkilised hävitavad invasioonid, piltide varingud sõnade keskele, verbaalsed välgusähvatused, mis õõnestavad ja lõhkavad joonistusi." ${ }^{\prime 3}$

Pangem tähele: piltide varingud sõnade keskele... Varisemine käib ju ülevalt alla? Kas see tähendab, et kunstiteosed paiknevad taas diskursuse pinnast kõrgemal, mitte selle all, nagu paistis „Teadmiste arheoloogias“? Kuid välgud (ka verbaalsed?) sähvivad ju samuti „,̈levalt alla“, mis peaks nagu tähendama, et sõnad seisavad kujutatust kõrgemal? Ilmselt ei saa siin enam piirduda rangelt kahetise jaotusega (vertikaalseks ja horisontaalseks), mistõttu võikski nimetada sellist kunstinägemisviisi sfääriliseks. Siin pole mingit väljapääsu ega teispoolset varjatust, on vaid dünaamilisus. Foucault kasutas kujutise ja teksti suhtest kõneldes sõja (polemos'e) kujundit ning Deleuze on samuti märkinud, et temas oli herakleitoslikkust rohkem kui Heideggeris, kellest tema tee viis lahku osaliselt ka sellepärast, et nii ontoloogia kui ka fenomenoloogia tundusid talle liiga „patsifitseerivatena“. Seevastu Foucault`le iseloomulikke „nähtavusi ei määratle ainult vaade, vaid need on ka tegevuste ja kirgede, aktsioonide ja reaktsioonide kompleksid, multisensoorsed kompleksid, mis tulevad valgusesse. ${ }^{\prime 34}$

32 Michel Foucault, See ei ole piip, tlk Kaia Sisask (Tallinn: Pelerine, 2004), 20-21.

Ibidem, 36.

34 Deleuze, Foucault, 66
Kui püüaksime nüüd visualiseerida foucault'likku „sõda“ pildi ja teksti vahel, paistab liikumine toimuvat korraga paljudes suundades, lausa läbisegi. „Nooled“ sõnade ja asjade vahel ei lenda sirgelt ei horisontaalis ega vertikaalis, vaid meenutavad pigem igimuutlikku keerist. Samas kõlab üks Herakleitose tuntumaid ütlusi nõnda: „Sõda on kõigi asjade isa." Ka sõnad ja pildid ei hävita üksteist selles sõjas, vaid nende loendamatutest kokkupõrgetest sünnib üha midagi uut. Piltide kui mittediskursiivsuse ja teksti kui diskursiivsuse läbipõimunud voog kandub nähtavana läbi kogu Michel Foucault' filosoofia.

$$
* * *
$$

Mõningaid selle voo sõlmpunkte püüdsimegi käesolevas töös vaadelda. Foucault‘ vaatepunkti ja pilku jälgides selgus, et oma esimesel loomeperioodil nägi ta pilte vertikaalselt loodumas, pinnale kerkimas ja seal võbelemas, mõnikord maast endast välja kasvamas. Sellisena iseloomustab kunstiteoseid otseses mõttes sügav ja salapärane seos hullusega, sõnatu lummusega, traagilise kosmilise kogemusega. Piltides väljendub inimese ohtlik vabadus, aga teisalt osutuvad need ka suhteliselt sõltumatuks autori enda tahtest ja otsustusvõimest - nimelt see teebki loomise ohtlikuks ja kunstiteosed lummavaks.

Teisel, rangemalt analüütilisel perioodil keskendus Foucault eelkõige diskursuserežiimidele ja nõnda vaadeldes osutus kunstki selle „pinnalise" režiimi raames ehk siis horisontaalselt teostuvaks praktikaks. Sellisena on kunst valdavalt "tingitud" tegevus ja kunstnik on oma loomingus palju vähem vaba, kui tavatsetakse arvata. Ainult et tema vabadust piirab nüüd sotsiaalne kude, mitte „,kosmilised jõud“. Just nagu strukturalistid (kelle hulka küll Michel Foucault ise ei soovinud ennast liigitada) tahtsid teha "lõpu subjekti laiutamisele ajaloolaval“, nii näib horisontaalne kunstipraktika tahtvat „teha lõppu kunstniku laiutamisele loomelaval“. Kolmas „nihe“, mis Foucault” kunstinägemises aset leidis, andis säärasest piltide ja sõnade, loomingu vabaduse ja tingituse igikestvast võitlusest varasemast jõulisema, rahutuma, isegi sõjakama pildi. Kunstinägemine muutus sfääriliseks.

Lõpetuseks... Lubatagu veel tagasi vaadates lihtsameelselt küsida: jah, aga mis siis? Mis tähtsust sellel kõigel on? Kas seesugusel vertikaalsel, horisontaalsel, sfäärilisel vaateviisil on üldse mingeid tagajärgi või vähemalt järeldusi? Või jääb kogu eelnev ekskurss ringkäiguks tavapärase 
sekundaarkäsitluse lamedal pinnal? Kenaks, kuid kasutuks klaaspärlimänguks? Viimasel juhul võikski selle retoorilise küsimusega artiklile punkti panna.

Aga siiski... Mingi aim või „perifeerne nägemine“ näib ütlevat, et kunsti nägemise suunal võib olla kaugemaid tagajärgi. Ehkki neid tõenäoliselt ei õnnestu piisavalt rangelt formuleerida, ei tähenda see, et need ei vääriks hüpoteesina visandamist.

Esimesena meenub märksõna „väärtus“. Väärtustamise probleem. Laiemas mõttes on vertikaalsuund juba iseenesest selle dimensiooniga lähemalt seotud. Vertikaalsus puudutab hierarhiat, alt üles vaatamist ehk austust. Lisandub seos pühaduse struktuuride ja sümboolikaga. Ise looduvad, kunstniku käe all kasvavad, kes teab mis jõudude ajel maapõuest esile kerkivad kunstiteosed äratavad teistsugust aukartust kui need, mida lihtsalt produtseeritakse lamedal pinnal. Ka Foucault tekste võrreldes torkab silma, et esimesel, „,vertikaalsel“ perioodil viitas ta kujutava kunsti teostele märksa rohkem kui hilisematel perioodidel. Vertikaalis looduvad pildid paistavad pakkuvat talle rohkem inspiratsiooni. Õigupoolest ainult sel perioodil ,ütlesid“ pildid talle midagi olulist, hiljem ütles ta pigem ise midagi piltide kohta. Lisaks tuleb tõdeda, et horisontaalset kunstikäsitlust ei kirjutanud ta kunagi valmis, vaid piirdus selle napi „kondikava“ visandamisega. Selline käsitusviis ei nõuagi, et vaadataks või "kuulataks" pilte endid, vaid pakub ühe võimaliku viisi nende „üle“ kõnelemiseks. Võib-olla Foucault lihtsalt ei jõudnud horisontaalset kunstikäsitlust kirjutada, võib-olla ei pakkunud see talle piisavalt pinget.

Edasi, horisontaalne kunstinägmine, eriti G. Dickie pakutud versioonis, on tarbijalik nägemine. Konsumeristlik. Kuid sõna consumption tähendas algselt - ja mitte nii väga ammu, alles 1920. aastatel - hävitamist, rüüstamist, alistamist, ärakulutamist; loomulik oli ütelda, et tuberkuloos „tarbis" inimesi. ${ }^{35}$ Kunst tähendab siis kunstiturgu, mille funktsioneerimise tagab nõudluse ja pakkumise suhe. Sel juhul aga kipuvad taiesed nakatuma tarbeesemetele omasesse „ühekordse kasutatavuse“ tõppe ja need, mille mõju kaldub kauem kestma, ähvardavad kaasa tuua majanduskrahhi. Vahest osutub tarbimisajastul kõige elujõulisemaks, olgugi et üksikeksemplarides väga lühiealiseks kujutamisviisiks tootedisain?

35 Jeremy Rifkin, Töö lõpp. Ülemaailmase töojjõu allakäik ja turujärgse ajastu koidik, tlk Mart Trummal (Tartu: Fontese Kirjastus, 1998), 36.
Mis kaunina omakorda „meeldib ja peab meeldima röövlooma inimene võimu-olemusele". ${ }^{36}$

Teiseks, märksõnad „vertikaalsus“ ja „maa“ tuletavad meelde liigagi lihtsa ja sellisena sageli ununeva tõsiasja, et kujutava kunsti teosed on (vähemalt seni on olnud) oma loomult materiaalsed ja sellisena sõna otseses mõttes maast tulnud - muud mateeriat ju inimkonnal kuskilt võtta ei ole. Igati tervemõistuslik on väita, et teosed tulevad maast ja tõusevad kunstniku kaasabil ilma avatusse, nagu Heidegger seda nägi. Öeldes eespool, et kujutava kunsti teosed on materiaalsed vähemalt seni, pidasime silmas arengut, mis kaldub muutma kunsti üksnes plinkivate valgustäppide konfiguratsiooniks arvutiekraanil. Ekraan on küll materiaalne, kuid kas ja kuivõrd või mis mõttes on materiaalsed ekraanil süttivad ja kustuvad valgustäpid ise? Nii või teisiti võib öelda, et virtuaalsed kujutised on materiaalsed teisiti, kui seda on "vana-aegsed“ maised taiesed. Foucault' sfääriline vaateviis võib ehk hästi sobida virtuaalse kunsti mõtestamiseks, kuid see ei ole enam käesoleva töö teema

Milline tulevik võiks aga virtuaalmaailma võidukäigu ajastul oodata materiaalset kunsti? Võib-olla paistavad kunstiteosed ja käsitööesemed tulevikus taas üksteisele lähedasemad, kui tänapäeval tavaks arvata. Käsitöö ei ole ju masstoodangu taustal oma väärtust ja väärikus kaotanud, vaid otse vastupidi - teatud mõttes on see isegi õilistunud. Käsitööoskus on taas ausse tõusnud ning käsitööesemeid eelistavad, seejuures ka tahavad ja saavad endale lubada vaid ühes või teises mõttes rikkad ja (asja)tundlikud inimesed. Võimalik, et sama tee läbivad materiaalsed kunstiteosed, millest igaüks on loomult unikaalne.

Tänapäevane tõerežiim (kui Foucault' terminit kasutada) ei luba vähemalt mitte tõsiseltvõetavalt - kõnelda materiaalse taiese vahetust füüsilisest mõjust vaatajale. Päris palju aega on möödunud sellest, kui toda teemat söandas puudutada Walter Benjamin oma essees „Kunstiteos oma tehnilise reprodutseeritavuse ajastul“ (1936), kus ta küsis, kuidas reprodutseeritavus kunstiteostele mõjub. Isegi kui see ei mõjuta originaali ennast (või kui me ei ole käesoleval hetkel võimelised seda mõju tuvastama), muutub ikkagi miski publiku suhtes teostega. Seda „miskit“, mis originaalil on ja koopial ei ole, nimetas ta auraks. „Mis see aura siis on? Ruumi ja aja ainukordne põiming - ainukordne nähtus, mida pakub

36 Heidegger, „Meelestus“, Kunstiteose algupära, 145. 
kaugus, nii lähedal, kui see olla võibki.."37 Aura kadumise tagajärjeks peab Benjamin esteetilise kogemuse vaesestumist, kärbumist, ja tema meelest tähendas see ränka kultuurilist vapustust. Ometi oli reprodutseeritavus tollal võrreldamatult väiksema võimusega kui tänapäeval. Foucault' tähenduses tõerežiimid on aga ajaloos muutuvad, mistõttu pole välistatud, et Benjamini intuitsioon võib kunagi uuel tasemel päevakorda tõusta.

Veel viimane märkus: siinkirjutajale on oma eriala, nimelt tõlkimise tuleviku üle mõtiskledes pähe tulnud, et tehnoloogiliste tõlkeprogrammide arenedes võib ka inimese tehtud tõlge nihkuda pigem käsitöö valda just nagu materiaalne kunstki. Nii nagu praegu peetakse lugu rätsepa õmmeldud ülikonnast ja kingsepa tehtud kingadest, nõnda ehk tellivad tulevikus endale inimtõlkeid veel vaid vähesed keele- või mõttegurmaanidest metseenid. Ja ehk antakse mõnele õnnestunud tõlkele siis koguni raamatu vorm - kes teab, äkki isegi nahakunstniku käe all valminud köites? Muuseas, kas pole isegi raamatud oma pabermateriaalsuses juba nihkumas pigem kujutava kunsti teoste valda? Tekstid elavad edukalt edasi virtuaalmaailmas, samal ajal kui raamatud jäävad ellu koos maiste, veel mateeriasse vermitud kunstiteoste ja käsitöötaiestega?

Mirjam Lepikult: Foucault's Philosophical Vision Based on the Example of Fine Art

Keywords: Foucault's art philosophy; Philosophical SeEInG; Martin Heidegger; george Dickie; vertical view; horizontal VIEW; SPHERIC VIEW

\section{SUMMARY:}

In examining Michel Foucault's philosophical vision I have used Gilles Deleuze's definition: "A seer is someone who sees something not seen." Being situated on the border between the discursive and the non-discursive, images offer an opportunity to get out of the discursivity; this

37 Walter Benjamin, „Kunstiteos oma tehnilise reprodutseeritavuse ajastul“, Valik esseid, tlk Mati Sirkel, Loomingu raamatukogu, 26-29 (2010), 119 . rupture enables one to see and say something new. The images carry in themselves "an uncertainty essential for creativity". This property relates images to Foucault's philosophical vision, aimed at destroying the evidence characteristic of a historical formation in the sphere of what is seen and what is said.

In addition, one can notice three different directions in Foucault's understanding of art, which correspond to different periods in his thinking. In his first work Folie et déraison. Histoire de la folie à l'âge classique (1961) there is a vertical view. Influenced by Martin Heidegger's ontological conception of art, Foucalt sees images as "growing out of the Earth", as a specific truth which he valued highly during this period."

Archéologie du savoir (1969) reveals a different vision of art. In this work, Foucault stressed that, at least in one of its dimensions, art is a discursive practice "at the most superficial (discursive) level". In this "superficial" phase, his account of art may be compared to George Dickie's institutional theory of art. I call the gaze moving along the surface the horizontal.

However, as early as the 1970s, Foucault's understanding of art becomes spherical: art lacks an ontological dimension; instead, images emerge in a historical fabric, within a network of power, as a result of complex interaction between various forces. Foucault participates in this "fight" mainly at the discursive level, but he does not suffocate images with text; instead, he revitalizes them, making them visible again in a novel way.

Eventually the question arises whether the direction of the view has an effect on the interpretation of art.

Firstly, there is the problem of value. In a broader wider perspective, the vertical is inherently tied to this. It touches on hierarchy, on looking up from below and the awe this invokes. A connotation is assigned to divine structures and the symbolic significance of such things. Growing from the artist's hand via forces unknown, self-made artworks thus evoke a different kind of reverence than those produced merely on a flat surface. Foucault's earlier works in his vertical period reference visual art notably more than his later works. Pictures made in the vertical seem to offer him more inspiration. It is only during this period that pictures speak to him, later it would be reversed - he would speak of the image.

Admittedly he never finished his horizontal interpretation, producing only a barebones sketch. Such an approach does not demand viewing or listening to the art itself, but rather offers a possible way to hold a dis- 
cussion on it. Maybe Foucault just did not have the time to write on the horizontal or maybe it simply did not engage him enough.

The horizontal approach, specifically the version put forth by Dickie is a consumer-centric vision. Art would mean a market that is based purely on supply and demand. With this approach, artworks tend to contract the one time use and disposability of commodities.

Secondly, there is the issue of visual art's material or virtual nature. Words like verticality and Earth remind us that art has been material (until now) and thus literally originates from the ground. One can easily argue that works come from the Earth and emerge with the help of the artist, as Heidegger claimed. If we say that artworks have been material until now, we draw attention to the evolution of art as a configuration of shining pixels on a computer screen. The screen may be material but how and in what way is the light emitted from the tiny points of light material? However one approaches it, the virtual image is material in a different way than traditional works of art. Might it be that Foucault's spherical view is a good fit for analyzing such virtual art?

CV:

Mirjam Lepikult (b. 1969) is an Estonian free-lance translator interested mainly in $20^{\text {th }}$ French philosophy. She has translated works by M. Foucault, T. Todorov, M. de Certeau, R. Barthes, P. Veyne, M. MerleauPonty, J. Maritain, J.-F. Lyotard, also J.-J. Rousseau, D. Diderot, etc. She has also published prefaces for works by M. Merleau-Ponty, J. Maritain, M. Foucault, as well as articles on Foucault's philosophy of education and the reception of M. Heidegger's philosophy in Estonian. Lectured at Tartu Art College, Eurouniversity (Estonia), Gustav Adolf Grammar School (Tallinn), and the University of Tartu Viljandi Culture Academy. 